\title{
MENELUSURI PARA RAJA MADURA DARI MASA PRA-ISLAM HINGGA MASA KOLONIAL
}

\author{
Wawan Hernawan \\ Dosen Fakultas Ushuluddin UIN Sunan Gunung Djati Bandung \\ Jl. A.H. Nasution 105 Cibiru, Bandung 40614, Indonesia. \\ E-mail:wanha99@yahoo.com
}

\begin{abstract}
The Madurese kings, of Western and Eastern part of Madura, have shown their exsistence in the history of archipelagic kings. However, their exsistence are less influenced and less famous compared to the kings of Java, Sunda or Bali origin. The investigation of Madurese kings (of Western and Eastern part of Madura) aims at finding the authenticity of their existences. This study is important to counter global figures idolisations and to shows the local people about their local ideals who have given significant contribution to the foundation of Indonesian history. This study employs historical research method to dig information on the reign of the kingdom. This study shows that: first, one source informed (the validity is unknown) concerning the genealogy of the story related to princes Bendoro Gung and Raden Segoro showed the trace of people coming to Madura from the West side through to the East. Second, in pre-Islamic period, based on several inscription and manuscript (kakawin, serat, kidung, dan $\mathrm{babad}$ ), showed that there are more information given to the role of Eastern Madurese than that of Western. The role of Western Madurese only available in Islamic period by providing the story of Prince Pratanu's journey to Mataram and back to West Madura (Bangkalan), then followed by several kings of Western Madura. Meanwhile, Eastern Madura kingdom (Sumenep) have been governed at least by 35 kings since Arya Wiraraja to Bendoro Abdurrahman. The journey of Madurese kings continued until the arrival of Vereenigde OostIndische Compagnie (VOC) and Dutch collonialism.
\end{abstract}

Keywords:

Colonial; exsistence; kidung; politics; supremacy.

\begin{abstract}
Abstrak
Para raja Madura (Barat dan Timur) telah menunjukkan eksistensinya dalam rangkaian sejarah para raja di Nusantara. Namun demikian, eksistensi mereka masih kalah pengaruh bila dibandingkan dengan para raja yang berasal dari Jawa, Sunda, dan Bali. Hal yang sama dalam pemberitaan media, meskipun mereka diakui, namun tidak sesubur informasi mengenai para raja Jawa, Sunda, dan Bali. Penelusuran terhadap para raja Madura (Barat dan Timur) bermaksud mencari dan mereguk otentisitas eksistensinya. Ini menjadi penting, di tengah pergumulan gaya hidup yang selalu mengidolakan tokoh global, kita mesti bersikap arif terhadap tokoh lokal yang mempunyai andil besar dalam upayanya menemukan sejarah bangsa. Dengan menggunakan metode penelitian sejarah, diperoleh informasi, bahwa pertama, dari sisi asal-usul, meskipun belum ditemukan sumber bereputasi, keberadaan sumber tradisi yang mengaitkan peristiwa puteri Bendoro Gung dan Radin Segoro, menunjukkan bahwa perjalanan manusia menuju Madura berawal dari barat menuju ke daerah paling timur. Kedua, pada masa pra-Islam berdasarkan sejumlah prasasti dan naskah (kakawin, serat, kidung, dan babad) lebih banyak menempatkan peran orang-orang Madura timur. Keberadaan Madura barat baru diungkap kembali pada masa Islam, dengan menempatkan perjalanan pangeran Pratanu ke Mataram yang kemudian kembali ke Madura Barat (Bangkalan) yang dilanjutkan oleh pararaja lainnya di kerajaan Madura barat. Sementara di kerajaan Madura Timur (Sumenep) telah dipimpin paling tidak oleh 35 orang raja, sejak Arya Wiraraja hingga Bendoro Abdurrachman. Perjalanan para raja di Madura terus berlanjut hingga masa Vereenigde OostIndische Compagnie (VOC), dan masa Kolonial Hindia Belanda.
\end{abstract}

Kata Kunci:

Kolonial; eksistensi; kidung; politik; supremasi.

DOI: http://dx.doi.org/10.15575/jw.v1i2.589

Received: March 2016 ; Accepted: October 2016 ; Published: November 2016

\section{A. PENDAHULUAN}

Minat untuk melakukan penelusuran dengan judul di atas, sebenarnya dimulai ketika peneliti bersama beberapa mahasiswa Strata 2 dan Strata 3 Bidang Ilmu Sejarah Fakultas Ilmu Budaya Universitas Padjadjaran 
melakukan Praktek Penelitian Lapangan (PPL) untuk dua mata kuliah, yaitu: Metode Sejarah dan Historiografi yang diampu oleh Nina $\mathrm{H}$. Lubis. Praktek Penelitian Lapangan itu dilaksanakan pada 18-21 November 2010 mulai dari situs Trowulan-Mojokerto hingga ke Aros Baya, Blega, dan Sampang (Madura Barat), serta Pamekasan, Keraton Sumenep, dan Pemakaman Asta Tinggi (Madura Timur). Praktek Penelitian Lapangan itu berupaya merekonstruksi Hubungan Kerajaan Sunda dan Majapahit, sekaligus melihat dari dekat tinggalan-tinggalan kerajaan Majapahit, baik berupa lisan, tulisan, atau benda. Dalam Praktek Penelitian Lapangan itu, selain dibimbing langsung oleh Nina H. Lubis, juga dipandu oleh Aminudin Kasdi, dan Ary Sapto (Ketua dan Sekretaris Masyarakat Sejarawan Indonesia (MSI) Cabang Jawa Timur).

Informasi pertama tentang adanya beberapa kerajaan dan pararaja di Madura diperoleh dari PusakaDunia.Com. ${ }^{1}$ Sumber ini menyebutkan, bahwa "sebelum abad ke-18, Madura terdiri dari kerajaan-kerajaan yang saling bersaingan". Dalam sumber itu disebutkan lebih lanjut, "akan tetapi sering pula bersatu dengan melaksanakan politik perkawinan". ${ }^{2}$ Informasi selanjutnya yang menggambarkan adanya persaingan antar kerajaan di Madura dinyatakan, bahwa ketika nama Madura disebut dalam sastra Jawa, selalu menunjuk kepada Madura Barat. Sementara Madura Timur, hampir tidak pernah diberitakan. ${ }^{3}$ Madura Barat yang letaknya berhadapan dengan Surabaya dan Gresik, tampak lebih diuntungkan dalam berbagai halnya dibandingkan dengan Madura Timur. Penyebaran penduduk ke Jawa yang jauh lebih luas dan makmur diduga merupakan faktor penting dalam bidang

\footnotetext{
${ }^{1}$ Anonimous, "Sejarah Asli Kerajaan Madura," diakses pada 18 November 2010, http://duniapusaka.com/index.php?route=product/product\&product id $=794$.

2 Anonimous, "Sejarah Asli Kerajaan Madura."

${ }^{3}$ Aminudin Kasdi ( +56 tahun, Ketua MSI Cabang Jawa Timur dan Guru Besar Universitas Negeri Surabaya/UNESA), wawancara oleh Wawan Hernawan, Madura, 19 November 2010.
}

ekonomi maupun sejarah politik orang Madura. ${ }^{4}$

Situasi dan kondisi itu, hemat peneliti, berbanding terbalik dengan suku-suku utama lainnya yang bertetangga dengan Jawa, seperti: Sunda dan Bali. Dari studi permulaan ${ }^{5}$ yang dilakukan peneliti, diperoleh informasi, bahwa memang orang Madura tidak mempunyai "sastra" (cerita tutur atau tradisi lisan) dalam bahasa sendiri (bahasa Madura) mengenai keberadaan raja-raja Madura pada zaman pra-Islam. Menurut cerita-cerita Madura yang masih dapat dijumpai, agaknya sejak jaman dahulu yang menjadi penguasa atas daerahdaerah Madura kebanyakan berasal dari Jawa atau selalu dikaitkan dengan Jawa. Selain itu, dijumpai pula informasi, bahwa kerajaankerajaan di Madura selalu berada di bawah supremasi dan hegemoni dari kerajaan yang lebih besar yang kekuasaannya berpusat di Jawa. ${ }^{6}$ Sebut saja misalnya, antara 1100-1700 M., berada di bawah supremasi kerajaan Hindu di Jawa Tengah dan Jawa Timur. Hal itu terus berlanjut sampai berdirinya kerajaankerajaan Islam di Pesisir Demak dan Surabaya, maupun pada masa kerajaan Mataram (Islam). ${ }^{7}$ Pada pertengahan abad ke-18, juga dijumpai informasi, Madura berada di bawah pengaruh Vereenigde Oost Indische Compagnie (VOC). ${ }^{8}$ Setelah VOC dibubarkan pada akhir abad ke-19, atau tepatnya pada 1879 M.,

\footnotetext{
${ }^{4}$ Aminudin Kasdi, wawancara oleh Wawan Hernawan.

${ }^{5}$ Lihat, H.J De Graaf dan TH. G Pigeaud, KerajaanKerajaan Islam di Jawa Peralihan dari Majapahit ke Mataram (Jakarta: Grafiti, 1985). Lihat pula, Zein M. Wiryoprawiro, Arsitektur Tradisional Madura Sumenep dengan Pendekatan Historis dan Deskriptif (Surabaya: Laboratorium Arsitektur Tradisional FTSP ITS Surabaya, 1986). Bandingkan dengan, Bendara Akhmad, Lintasan Sejarah Sumenep dan Asta Tinggi Beserta Tokoh di Dalamnya (t.k.: Barokah, 2010).

${ }^{6}$ Bangkalan Memory, "Madura Menurut Catatan Sejarah," diakses pada 17 November 2010, http://www.bangkalanmemory.net/content/view/163/147/.

${ }^{7}$ Memory, "Madura Menurut Catatan Sejarah.".

8 Hamdani Lubis, "Sejarah Madura," Kabar Madura, diakses pada 10 Januari 2016, http://kabarmadura07.blogspot.co.id/2013/01/sejarahmadura.html.
} 
Madura secara berangsur-angsur menjadi bagian dari penguasa Kolonial (pemerintah Hindia Belanda) sampai masa Dai Nippon (pemerintah Pendudukan Jepang). ${ }^{9}$

Uraian di atas menunjukkan, pertama, di Madura telah berdiri beberapa kerajaan. Kerajaan itu terus saling berebut pengaruh hingga sebelum abad ke-18. Meskipun demikian, terkadang mereka bersatu melalui perkawinan. Kedua, orang Madura tidak mempunyai "sastra" (cerita tutur atau tradisi lisan) dalam bahasa sendiri (bahasa Madura) mengenai keberadaan raja-raja mereka pada zaman pra-Islam, sehingga eksistensi mereka kalah pengaruh bila dibandingkan dengan para raja dari Jawa, Sunda, dan Bali. Hal yang sama dalam pemberitaan media, meskipun eksistensi mereka diakui, namun tidak sesubur informasi mengenai pararaja Jawa, Sunda, dan Bali. Ketiga, bertolak dari beberapa masalah tersebut, kemudian dijadikan pertanyaan penelitian, yaitu: (a) Bagaimana dan mengapa Madura? (b) Bagaimana sastra kuno menceritakan Madura? (c) Bagaimana dan mengapa pararaja Madura?

Penelitian tentang "pararaja Madura" bermaksud mencari dan mereguk otentisitas eksistensinya. Penelitian ini juga diharapkan memiliki manfaat teoretis (keilmuan) dan praktis. Secara teoretis, penelitian ini diharapkan dapat bermanfaat bagi perkembangan studi sejarah, khususnya sejarah politik di Indonesia. Sementara secara praktis, penelitian ini diharapkan dapat memberi pengetahuan historis bagi berbagai kalangan yang membutuhkan. Manfaat praktis lainnya, tentu saja ikut berpartisipasi dalam mengisi literatur yang mengetengahkan "para raja Madura" mengingat eksistensi mereka merupakan rangkaian sejarah para raja di Nusantara. Hasil dari penelitian ini juga diperuntukkan bagi siapa saja untuk mengingat-ingat dan menelaahnya dengan seksama.

Metode yang digunakan dalam penelitian ini adalah metode penelitian sejarah yang meliputi empat tahap, yaitu heuristik, kritik,

\footnotetext{
${ }^{9}$ Lubis, "Sejarah Madura."
}

interpretasi, dan historiografi. ${ }^{10}$ Dalam tahapan heuristik, peneliti mengumpulkan tiga jenis sumber, yaitu: pertama sumber-sumber tertulis berupa buku, dokumen, artikel dalam koran, dan artikel dalam web site. Kedua, sumber lisan yang diperoleh dari wawancara. Ketiga, sumber benda berupa patung, nisan, bangunan, photo, dan gambar. Langkah selanjutnya menuju ke tahapan kritik. Sumber yang telah ditemukan dalam tahapan heuristik harus diuji terlebih dahulu melalui kritik atau ferivikasi yang terdiri dari kritik eksternal dan kritik internal. Melalui kritik ini diharapkan otentisitas dan kredibilitas sumber dapat ditentukan dan teruji. Selanjutnya, untuk menghasilkan fakta sejarah, data yang berasal dari sumber teruji tersebut perlu mendapatkan pendukungan dari dua atau lebih sumber lain yang merdeka satu sama lain atau koroborasi. Setelah melalui tahapan kritik, kemudian dilakukan interpretasi terhadap fakta dari sumber teruji tersebut. Interpretasi dilakukan dalam dua proses, yaitu analisis (menguraikan) dan sintesis (menyatukan). Dalam tahap inilah digunakan teori atau konsepkonsep ilmu sosial untuk membantu menjelaskan fakta-fakta sejarah. Dengan demikian, penelitian "Menelusuri Para Raja Madura: Napak Tilas Tinggalan Kerajaan Madura dari Sampang, Aros Baya, Blega, Pamekasan, sampai Sumenep" di samping berbentuk deskriptif-naratif sekaligus deskriptif-analitis yang digunakan secara bersamaan. ${ }^{11}$ Tahapan terakhir adalah tahapan historiografi. Tahapan ini sebagai penyampaian hasil rekonstruksi imaginatif masa lampau sesuai dengan trace (jejak-jejak) dan fact (fakta). Dalam tahapan

${ }^{10}$ Gilbert J. Garaghan, A Guide to Historical Method, (New York: Fordham University Press, 1946), 103-426. Lihat, Louis Gottschalk, Mengerti Sejarah, terj. Nugroho Notosusanto (Jakarta: Yayasan Penerbit Universitas Indonesia, 1975), 32. Lihat pula, G.J. Renier, Metode dan Manfaat Ilmu Sejarah, terj. A. Muin Umar (Yogyakarta: Pustaka Pelajar, 1997), 118. Bandingkan dengan, Nina H. Lubis, Metode Sejarah (Bandung: Satya Historika, 2008), 17-60.

${ }^{11}$ Sartono Kartodirdjo, Pendekatan Ilmu Sosial dalam Metodologi Sejarah (Jakarta: Gramedia, 1992), 21. Lihat pula, Helius Sjamsuddin, Metodologi Sejarah, terj. S. Aji (Yogyakarta: Ombak, 2007), 158. 
terakhir ini diperlukan kemahiran art of writing (seni menulis). ${ }^{12}$

\section{B. HASIL DAN PEMBAHASAN}

\section{Asal Usul dan Karakter Orang Madura}

Terma Madura yang menunjuk pengertian pulau di sebelah timur laut provinsi Jawa Timur disebut pula pulau Madura. Dewasa ini, Madura telah memasuki kehidupan masyarakat Indonesia, meliputi: pengertian kebudayaan, etnis, geografis, administrasi pemerintahan, dan sosial. ${ }^{13}$ Selain itu, Madura juga telah menjadi objek kajian dunia ilmu pengetahuan terutama ilmu-ilmu sosial dan humaniora yang membahas tentang kebudayaan dan daerah Madura. ${ }^{14}$

Terdapat informasi, nama Madura telah dikenal sejak abad ke-13, atau mungkin sebelumnya. Pendapat tersebut berdasar kepada Prasasti Kudadu yang dikeluarkan oleh Kertarajasa Jayawardhana pada 1216 Ç (11 September 1294) guna memeringati pemberian anugerah raja kepada para pejabat desa (râma) di Kudadu yang dipandang berjasa kepada negara melalui bantuan mereka ketika raja dikejar dan terdesak oleh pasukan Kadiri. Dalam prasasti itu, disebutkan dari Kudadu Raden Wijaya yang masih memimpin pasukan --yang tinggal 12 orang-- diantar ke Rembang untuk kemudian pergi ke Madura bersama istri dan pengiringnya. ${ }^{15}$ Prasasti lain yang menjelaskan eksistensi Madura adalah Prasasti Sukamerta yang berangka tahun 1218 Ç (29 Oktober 1296). Prasasti ini pun masih dikeluarkan oleh Kertarajasa guna memeringati penetapan desa Sukamerta sebagai desa swatantra atas permohonan Panji Patipati $\mathrm{Pu}$ Kapat yang telah menunjukkan kebaktian dan

\footnotetext{
${ }^{12}$ Garaghan, A Guide to Historical Method, 18,143.

${ }^{13}$ Wiryoprawiro, Arsitektur Tradisional Madura Sumenep dengan Pendekatan Historis dan Deskriptif, $\mathrm{xV}$-Xviii.

${ }^{14}$ Wiryoprawiro, Arsitektur Tradisional Madura Sumenep dengan Pendekatan Historis dan Deskriptif, 2-14.

${ }^{15}$ Hasan Djafar, "Kerajaan Majapahit," dalam Indonesia dalam Arus Sejarah, Jilid 2 (Jakarta: Ichtiar Baru van Hoeve atas kerjasama dengan Kementerian Pendidikan dan Kebudayaan Republik Indonesia, 2012), 239.
}

kesetiaan kepada raja. Dalam prasasti Sukamerta juga disebutkan, bahwa Raden Wijaya menyeberangi lautan menuju Madura. Setibanya di Madura, ia diterima oleh Arya Wiraraja salah seorang mantan bawahan Raja Kertanagara. ${ }^{16}$

Leluhur orang Madura --orang pertama yang mendiami dan pemukim pertama di pulau Madura-- belum dapat diketahui secara pasti. ${ }^{17}$ Berita, prasasti, atau tinggalan lainnya yang memberikan informasi ke arah itu belum ditemukan. Namun demikian, berdasarkan sumber tradisi, diinformasikan bahwa cikalbakal dan pemukim pertama di pulau Madura sering dikaitkan dengan cerita Radin Segoro (Kesatria Lautan). ${ }^{18}$ Menurut sumber ini, Radin Segoro adalah anak dari puteri Bendoro Gung yang dihanyutkan ke tengah laut oleh Patih Pranggulang ketika masih dalam kandungan ibunya. Puteri Bendoro Gung kelak terdampar di sekitar gunung Geger (daerah Bangkalan sekarang). Daratan itu kemudian disebut "Madu Oro," yaitu pojok di ara-ara atau diartikan pula pojok menuju ke arah yang luas. ${ }^{19}$ Terdapat informasi, orang tua puteri Bendoro Gung adalah Sanghyang Tunggal seorang raja dari Negeri Medang. Terkait dengan nama Sanghyang Tunggal, Larope dan Soetedjo $^{20}$ menyebutkan, bahwa diduga yang dimaksud adalah Rakai Panunggalan ${ }^{21}$ raja ketiga Kerajaan Medang Kamulan di Poh Pitu. Masih dalam sumber tradisi, pada suatu ketika

\footnotetext{
${ }^{16}$ Djafar, "Kerajaan Majapahit."

${ }^{17}$ Abdurachman, Sejarah Madura Selayang Pandang (Sumenep: The Sun, 1971), 1-4. Lihat pula, Wiryoprawiro, Arsitektur Tradisional Madura Sumenep dengan Pendekatan Historis dan Deskriptif, 23.

${ }^{18}$ Wiryoprawiro, Arsitektur Tradisional Madura Sumenep dengan Pendekatan Historis dan Deskriptif.

${ }^{19}$ A. Latif Wiyata, Mencari Madura (Jakarta: Bidik Phronesis Publishing, 2013), 3.

${ }^{20}$ J. Larope dan R. Soetedjo, Sejarah Indonesia (Surabaya: Asia-Afrika, 1975), 18. Lihat pula, Wiryoprawiro, Arsitektur Tradisional Madura Sumenep dengan Pendekatan Historis dan Deskriptif, 24.

${ }^{21}$ Nama Rakai Panunggalan tercantum dalam prasasti Mantyāsih yang berisi rahyang ta rumuhun ri mdang ri poh pitu (urutan nama-nama raja Medang di Poh Pitu). Lihat, Marwati Djoened Poesponegoro dan Nugroho Notosusanto, Sejarah Nasional Indonesia, Jilid II, (Jakarta: Balai Pustaka, 1993), 118.
} 
kerajaan Medang diserang oleh pasukan dari China. Di dalam peperangan tersebut Kerajaan Medang berkali-kali menderita kekalahan, hingga pada suatu hari mereka didatangi oleh seorang tua. Orang tua itu mengatakan, bahwa di Pulau Madu Oro tinggal seorang anak muda yang bernama Radin Segoro. Raja Medang Kamulan dianjurkan untuk meminta bantuan kepadanya, jika ingin menang dalam perang melawan pasukan China tersebut. Singkat cerita, Radin Segoro ${ }^{22}$ berangkat menuju Kerajaan Medang dengan membawa senjata yang diberi nama si Nengolo. Dalam pertempuran yang dipimpinnya banyak tentara China yang tewas, sehingga kerajaan Medang terbebas dari kekuasaan dan pengaruh mereka. ${ }^{23}$

Dilihat dari bentangan sejarahnya, Madura dicatat sebagai etnis yang terlalu lama dan bahkan sering berada di bawah supremasi etnis dan bangsa lain. Kondisi itulah yang diduga membentuk karakter dan kepribadian mereka menjadi teguh pada prinsip. Salah satu prinsip orang Madura, sebut saja misalnya, mereka mampu mengambil dan menarik manfaat yang dilakukan dari hasil budi orang lain, tanpa mengorbankan kepribadiannya sendiri. ${ }^{24}$ Mereka pada umumnya sangat menghargai dan menjunjung tinggi solidaritas kepada orang lain. Karakter dan kepribadian seperti itu, menjadikan orang-orang Madura di luar pulau Madura mudah dikenal. Mereka lebih supel dalam bergaul dan menunjukkan sikap toleran terhadap sesamanya. ${ }^{25}$ Karakter dan kepribadian lainnya, jika mereka kedatangan tamu --apalagi tamu yang datang dari jauh-- dapat dipastikan tamu tersebut akan

${ }^{22}$ Cerita yang hampir sama dengan kisah ini diulas oleh Soewito Santoso dalam Babad Tanah Jawi (Galuh-Mataram) dengan tokoh Jaka Sengara. Lihat, Soewito Santoso, Babad Tanah Jawi (Galuh-Mataram) (Delanggu: t.p., 1970), 189-193.

${ }^{23}$ Lubis, "Sejarah Madura."

${ }^{24}$ Syaf Anton, "Adat dan Kepribadian Orang Madura," Lomatar Madura, diakses pada 15 September 2016, http://www.lontarmadura.com/adat-dankepribadian-orang-madura-2/.

${ }^{25}$ Famela Fitria Scharlita, "Adat dan Kepribadian Orang Madura," 2013, http://famelasfitriascharlita. blogspot.co.id/2013/02/adat-dan-kepribadian-orangmadura.html. dilayani dengan baik. Orang Madura berani berkorban untuk menjamu tamunya. Bahkan jika perlu, mereka akan berusaha memuaskan tamunya dengan jamuan lebih, meskipun dengan cara berhutang. ${ }^{26}$ Namun demikian hal sebaliknya, jika penghargaan yang telah mereka berikan itu ditolak, seperti enggan mencicipi hidangan yang mereka suguhkan, tamu tersebut dipandang telah menginjak harga diri mereka. Di situlah mulai tumbuh benih-benih rasa benci dan dendam. ${ }^{27}$

Selain itu, sebagai etnis yang hidup di daerah kepulauan, orang Madura masa lalu kurang mendapat kesempatan dalam berinteraksi dengan dunia luar. Situasi dan kondisi ini pun diduga kuat ikut membentuk karakter dan kepribadian mereka. Orang Madura menjadi sangat berhati-hati. Sesuatu yang datang dari luar bagi mereka adalah ancaman terhadap dirinya. ${ }^{28}$ Pada sisi ini mereka akan berusaha memelihara dan menjamin nilai-nilai yang mengakar dalam dirinya. Namun demikian, pada orang Madura kekinian, meskipun menunjukkan naluri yang kuat dalam menjamin dan bertahan hidup, mereka pun didorong untuk menerima dan memanfaatkan nilai-nilai yang terserap dari luar. ${ }^{29}$

\section{Madura dalam Sastra Jawa Kuno}

Keunggulan seni menulis para pujangga pulau Jawa masa lalu --puisi, kakawin, serat, atau kidung-- yang dinamakan kalangon atau kalangwan, telah diakui dunia. Berdasarkan hasil penelitian para ahli, diinformasikan, bahwa sebagian besar karya sastra Jawa Kuno berhasil diselamatkan dalam keadaan lebih baik daripada monumen-monumen yang berbahan dasar batu (candi, prasasti, patung, lingga, dan lainnya). ${ }^{30}$ Dari hasil temuan para ahli itu, beberapa di antaranya menyebut tentang eksistensi orang Madura dalam hubungannya dengan kerajaan-kerajaan yang ada di

\footnotetext{
${ }^{26}$ Anton, "Adat dan Kepribadian Orang Madura."

${ }^{27}$ Anton, "Adat dan Kepribadian Orang Madura."

${ }^{28}$ Anton, "Adat dan Kepribadian Orang Madura."

${ }^{29}$ Anton, "Adat dan Kepribadian Orang Madura."

${ }^{30}$ P.J. Zoetmulder, Kalangwan Sastra Jawa Kuno Selayang Pandang, terj. Dick Hartoko Sj (Jakarta: Djambatan, 1974), XI.
} 
Jawa. Sebut saja misalnya, Kitab Pararaton, Kitab Nāgarakrtāgama (Kakawin Désawarnana), Kidung Rangga Lawe, Kidung Panji Wijayakrama, dan Kidung Harsawijaya. ${ }^{31}$

Kitab Pararaton atau kadang disebut Serat Pararaton atau ada yang menyebut pula Katuturanira Ken Angrok. Kitab ini ditulis pada abad ke XV dalam bentuk prosa (gancaran). ${ }^{32}$ Karena itu, berdasarkan perkiraan tahun penulisannya, kitab ini dapat dikelompokkan ke dalam naskah sastra Jawa masa Pertengahan yang digubah ke dalam bahasa Kawi. Kitab ini sangat ringkas, yaitu hanya 32 halaman seukuran kertas folio sekarang dan terdiri dari 1126 baris. Isi kitab ini secara umum mengetengahkan tentang para raja yang memerintah di Kerajaan Singhasari dan Majapahit. Kitab ini juga dikenal dengan nama Kitab Pustaka Raja atau dalam bahasa Sanskerta berarti kitab raja-raja. Suatu yang agak disesalkan dari kitab ini, tidak terdapat catatan yang menunjukkan penulisnya. ${ }^{33}$

Kitab Nāgarakrtāgama atau ada yang menyebut Kakawin Désawarnana disebut pula Kakawin Pujasastra Negarakretagama. Karya sastra Jawa Kuno yang disusun oleh Mpu Prapanca ini diperkirakan ditulis antara tahun 1359-1365 ini terdiri dari 98 pupuh yang dibagi ke dalam dua bagian. Bagian pertama terdiri dari pupuh 1- 49, sedangkan bagian kedua dimulai dari pupuh 50 - 98. Orang yang berjasa menemukan kembali kitab ini adalah $\mathrm{J}$. L. A. Brandes pada 1894 dalam sebuah ekspedisi ke Lombok dan menerbitkannya pada $1902 .^{34}$ Kitab ini pada masa selanjutnya termasuk karya yang paling banyak diteliti. Di antara para ahli yang pernah melakukan penelitian Kitab Nāgarakrtāgama adalah Kern, Krom, Pigeaud, dan P.J. Zoetmulder. ${ }^{35}$

Kidung Rangga Lawe, Kidung Panji Wijayakrama, dan Kidung Harsawijaya menurut Zoetmulder mempunyai ciri umum yang sama, yaitu bersumber dari tradisi historis Kerajaan Majapahit. ${ }^{36}$ Karya sastra Jawa Kuno dalam bentuk kidung ini mulai mendapat perhatian setelah Berg secara khusus menulis tesisnya mengenai tradisi historis Jawa Pertengahan pada 1926. Melalui upayanya itu, Kidung Rangga Lawe pernah diedisi pada 1931, Kidung Harsawijaya pada 1932, dan Kidung Panji Wijayakrama atau ada yang menyebut Kidung Sorandaka pada $1938 .{ }^{37}$

Madura dalam hubungannya dengan kerajaan-kerajaan yang ada di Jawa dimulai dari informasi Kitab Nāgarakrtāgama mengenai masuknya Madura di bawah supremasi Kèrtanāgara. ${ }^{38}$ Pada waktu yang lain, Kitab Pararaton menginformasikan mengenai pemecatan Arya Wiraraja dari dari jabatannya sebagai Demung (Rakryan Demung) Kerajaan Singhasari menjadi seorang Adipati di Sumenep. ${ }^{39}$ Selanjutnya, sebagai Adipati di Sumenep, berita tentang Arya Wiraraja tidak banyak diketahui, kecuali hubungannya dengan Jayakatwang (Jayakatong), raja dari Gelang-gelang dalam pemberontakannya terhadap Kèrtanāgara, dan hubungan dengan Wijaya ketika mengusir pasukan China (Tartar), serta pembangunan hutan Tarik (Wilwatikta). Setelah menobatkan dirinya sebagai raja Majapahit, Wijaya kemudian bergelar Srï Kèrtarājasa Jāyawarddhāna. Informasi itu terdapat dalam Kitab Pararaton, Kidung Harsawijaya, dan Kidung Panji Wijayakrama dengan sedikit perbedaan di

\footnotetext{
${ }^{35}$ Zoetmulder, Kalangwan Sastra Jawa Kuno Selayang Pandang, 444.

${ }^{36}$ Zoetmulder, Kalangwan Sastra Jawa Kuno Selayang Pandang, 512.

${ }^{37}$ Zoetmulder, Kalangwan Sastra Jawa Kuno Selayang Pandang.

${ }^{38}$ Poesponegoro dan Notosusanto, Sejarah Nasional Indonesia, Jilid II, 412.

${ }^{39}$ Poesponegoro dan Notosusanto, Sejarah Nasional Indonesia, Jilid II, 418.
} 
sana-sini. ${ }^{40}$ Nama-nama tokoh Madura lainnya yang disebutkan pada kakawin dan kidungkidung tersebut adalah Pu Sora dan Pu Nambi.

Sementara Kidung Rangga Lawe memulai kisahnya dengan menyebutkan, bahwa Ranggalawe merupakan salah seorang pengikut Wijaya yang berjasa dalam perjuangan mendirikan Kerajaan Majapahit. Namun demikian, ia meninggal sebagai "pemberontak" pertama dalam sejarah kerajaan itu. Meskipun demikian, nama besarnya oleh masyarakat Tuban sampai saat ini dikenang sebagai pahlawan. ${ }^{41}$ Dalam Kidung Rangga Lawe disebutkan, pada 1292, ia diminta untuk membantu Wijaya membuka hutan di sebelah barat Tarik (daerah Sidoarjo sekarang). ${ }^{42}$ Dijumpai informasi, nama Ranggalawe sendiri merupakan pemberian Wijaya. Lawe merupakan sinonim dari wenang, berarti "benang", atau dapat juga bermakna "kekuasaan". Sedangkan Ranggga berarti kecerdasan dan kebijaksanaan dalam menjalankan politik, sehingga tahu apa yang harus dilakukan. Maksudnya ialah, Ranggalawe diberi kekuasaan oleh Wijaya untuk memimpin pembukaan hutan itu. ${ }^{43}$ Atas jasajasanya, Rangga Lawe kemudian diangkat menjadi Adipati Tuban yang waktu itu merupakan pelabuhan utama di tanah Jawa bagian timur. ${ }^{44}$ Kitab Pararaton mengisahkan Rangga Lawe memberontak terhadap Kerajaan Majapahit, karena terlebih dahulu dihasut oleh seorang pejabat licik bernama Mahapati. Disebutkan pula, pemberontakan Ranggalawe tersebut terjadi pada $1295 .{ }^{45}$

\footnotetext{
${ }^{40}$ Poesponegoro dan Notosusanto, Sejarah Nasional Indonesia, Jilid II, 418-421.

${ }^{41}$ Slamet Muljana, Menuju Puncak Kemegahan (Sejarah Kerajaan Majapahit) (Yogyakarta: LKiS, 1985), 217-218.

${ }^{42}$ Poesponegoro dan Notosusanto, Sejarah Nasional Indonesia, Jilid II, 428-430.

${ }^{43}$ Zoetmulder, Kalangwan Sastra Jawa Kuno Selayang Pandang, 520-521.

${ }^{44}$ Slamet Mulyana, Nāgarakrtāgama dan Tafsir Sejarahnya (Jakarta: Bhratara Karya Aksara, 1979), 103-104.

${ }^{45}$ Poesponegoro dan Notosusanto, Sejarah Nasional Indonesia, Jilid II, 429.
}

\section{Eksistensi Para Raja Madura}

\section{a. Para Raja Madura Barat}

Sejarah Madura Barat yang berbentuk legenda dimulai dengan hadirnya seorang raja di Gili Mandangin (Sampang sekarang), bernama Lembu Peteng. Ia diduga masih keturunan raja Brawijaya ${ }^{46}$--salah seorang penguasa Majapahit-- melalui perkawinannya dengan puteri Campa. Nama Lembu Peteng sendiri menjadi petunjuk mengenai hubungan Madura dengan Jawa. ${ }^{47}$ Sedangkan Gili Mandangin yang menunjuk pulau kecil di Selat Madura merupakan pentas bagi balada Madura tentang sang Bangsacara. Menurut sumber tradisi, balada itu mengetengahkan cerita dua insan yang dipersatukan dalam kematian. ${ }^{48}$ Dalam Sadjarah Dalem, disebutkan, puteri Lembu Peteng dari Sampang diperisteri oleh putera Maulana Iskak. ${ }^{49}$ Informasi serupa juga diperoleh dalam tradisi lisan tentang keberadaan orang-orang suci di Blambangan. ${ }^{50}$ Disebutkan, Maulana Iskak adalah ayah Sunan Giri. Ia menikahkan salah seorang putranya dengan puteri Lembu Peteng dari Gili Mandangin. Dengan demikian, pada paruh kedua abad XV di Madura (Barat) para penguasa Jawa dan orang-orang Islam dari Campa mengadakan kontak. Kontak itu bahkan melalui perkawinan. ${ }^{51}$

\footnotetext{
${ }^{46}$ Hemat peneliti, nama Brawijaya bukan nama sebenarnya. Sebab nama itu tidak ditemukan dalam silsilah pararaja Majapahit. Bhra adalah singkatan dari Bhatara yang berarti baginda. Dalam hubungan ini, nama Brawijaya yang dimaksud adalah Dyah Ranawijaya berdasar prasasti Jiyu (1486). Dalam prasasti itu disebutkan, Ranawijaya adalah penguasa Majapahit, Janggala dan Kadiri yang berpusat di Daha. Kuat dugaan, Daha waktu itu merupakan ibukota Majapahit.

${ }^{47}$ H.J De Graaf dan TH. G Pigeaud, KerajaanKerajaan Islam di Jawa Peralihan dari Majapahit ke Mataram (Jakarta: Grafiti, 1985), 211.

${ }^{48}$ De Graaf dan Pigeaud, Kerajaan-Kerajaan Islam di Jawa Peralihan dari Majapahit ke Mataram.

${ }^{49}$ De Graaf dan Pigeaud, Kerajaan-Kerajaan Islam di Jawa Peralihan dari Majapahit ke Mataram,

${ }^{50}$ Ary Sapto (49 tahun), Sekretaris MSI Cabang Jawa Timur, wawancara tanggal 20 November 2010.

${ }^{51}$ De Graaf dan Pigeaud, Kerajaan-Kerajaan Islam di Jawa Peralihan dari Majapahit ke Mataram, 212.
} 
Menurut catatan Tome Pires, pada permulaan abad XVI, raja Madura masih belum memeluk Islam. Namun mereka dapat hidup berdampingan dengan para penguasa di Gresik. Dalam Daftar Tahun Peristiwa Demak yang menyebutkan daerah-daerah yang berhasil ditaklukkan oleh Kerajaan Demak, nama Madura juga tidak disebut. Terdapat dugaan, berdasarkan cerita Madura, pada waktu itu meskipun raja belum memeluk Islam, namun putera mahkota mereka (Madura Barat) telah memeluk Islam pada 1528. Karena itu, Demak tidak melakukan ekspansi ke Madura. ${ }^{52}$

Masih dalam Daftar Tahun Peristiwa Demak, disebutkan, bahwa pada 1527 raja Tuban tunduk kepada Penguasa Demak. Menurut sumber tradisi, keturunan raja Tuban, seperti juga keturunan raja Madura Barat masih memiliki hubungan kekerabatan dengan keluarga Majapahit. Kuat dugaan pula, sikap Tuban pada 1527 , telah memengaruhi sikap Madura Barat. Munculnya pahlawan yang menaklukkan Kerajaan Majapahit yang kelak bergelar Sunan Kudus ${ }^{53}$ dalam riwayat itu, dimungkinkan mengandung kebenaran, bahwa keluarga raja Madura Barat --yang sebagian besar karena pertimbangan-pertimbangan politik kekeluargaan-- mengambil sikap damai dengan Kerajaan Demak. Seiring dengan riwayat itu, putera mahkota yang memeluk Islam dari Madura Barat adalah Pratanu. Ia sebelumnya akrab dipanggil Pangeran Pragalba di istana Plakaran. Pada masa selanjutnya, Pratanu mendapat julukan Pangeran Ongguq atau Panembahan Lemah Duwur di Aros Baya. ${ }^{54}$

Suatu yang agak disesalkan, dalam sumber tradisi itu tidak dimuat pemberitaan tentang bantuan Raja Madura Barat kepada Kerajaan Demak dalam peperangan melawan para penguasa Jawa yang sebelumnya menjadi raja bawahan Majapahit. Karena itu, sulit diberi

\footnotetext{
${ }^{52}$ De Graaf dan Pigeaud, Kerajaan-Kerajaan Islam di Jawa Peralihan dari Majapahit ke Mataram.

${ }^{53}$ De Graaf dan Pigeaud, Kerajaan-Kerajaan Islam di Jawa Peralihan dari Majapahit ke Mataram,13.

${ }^{54}$ De Graaf dan Pigeaud, Kerajaan-Kerajaan Islam di Jawa Peralihan dari Majapahit ke Mataram.
}

interpretasi mengenai apakah dalam penyerangan terhadap Pasuruan --yang menurut sumber Portugis disebut Panarukan-- orang-orang Madura telah berjuang untuk pihak Kerajaan Demak seperti yang dilakukan oleh orangorang Surabaya? Untuk itu, muncul beberapa dugaan, di antaranya bahwa Panembahan Lemah Duwur yang sepanjang hidupnya telah menyibukan diri untuk memperluas kekuasaan atas daerah-daerah kecil merupakan bagian dari upayanya dalam membantu Kerajaan Demak. Dugaan tersebut dikuatkan oleh sumber tradisi yang berasal dari Madura Barat, bahwa Panembahan Lemah Duwur telah meluaskan kekuasaannya hingga ke wilayah Balega dan Sampang. ${ }^{55}$ Hal itu disamping sebagai upaya membantu perluasan wilayah kekuasaan Demak, sekaligus sebagai upaya bakti karena ibunya berasal dari Pamandegan, Sampang. Panembahan Lemah Duwur meninggal pada $1590 .^{56}$ Menurut Sadjarah Dalem, setelah Pangeran Lemah Duwur meninggal, kepemimpinan di Aros Baya dilanjutkan oleh salah seorang anaknya bernama Panembahan Tengah. ${ }^{57}$

Pada perjalanannya, Kerajaan Madura Barat kemudian ditundukkan oleh Mataram pada $1624 .{ }^{58}$ Ketika menjelang keruntuhannya, Pangeran Mas melarikan diri ke Giri, sedangkan Prasena (putera ketiga Pangeran Tengah) dibawa oleh Juru Kitting ke Mataram. Prasena kemudian dijadikan anak angkat oleh Sultan Agung. Setelah dewasa ia dilantik menjadi penguasa untuk seluruh Madura. Guna menguatkan posisinya ia digelari Tjakraningrat $\mathrm{I}^{59}$ Ia kemudian memindahkan pusat Kera-

\footnotetext{
${ }^{55}$ De Graaf dan Pigeaud, Kerajaan-Kerajaan Islam di Jawa Peralihan dari Majapahit ke Mataram.

${ }^{56}$ De Graaf dan Pigeaud, Kerajaan-Kerajaan Islam di Jawa Peralihan dari Majapahit ke Mataram, 214.

${ }^{57}$ Aminudin Kasdi, wawancara oleh Wawan Hernawan.

${ }^{58}$ Lihat, De Graaf dan Pigeaud, Kerajaan-Kerajaan Islam di Jawa Peralihan dari Majapahit ke Mataram, 215. Lihat pula, Muhammad Syamsu As, Ulama Pembawa Islam di Indonesia dan Sekitarnya, (Jakarta: Lentera, 1996), 91.

${ }^{59}$ Nama Cakraningrat diberikan pada tahun 1678 sebagai hadiah Mangkurat II kepada anak Prasena dari Sampang ketika diangkat menjadi Patih. Mengikuti
} 
jaan Madura Barat dari Arosbaya ke Sampang. Setelah meninggal, para keturunannya mengembangkan kerajaan baru di Madura, termasuk Bangkalan. Tjakraningrat I menikah dengan adik Sultan Agung, ${ }^{60}$ namun tidak mempunyai keturunan. Baru dari pernikahannya dengan Ratu Ibu (Syarifah Ambani, keturunan Sunan Giri), ia memperoleh tiga orang putra. Ia pun mendapatkan beberapa orang anak dari beberapa selir. ${ }^{61}$

Pada 1743, Vereenigde Oost-Indische Compagnie (VOC) mengadakan pembatasan serta penindasan terhadap kekuasaan raja dan rakyat Madura. Karena itu, di Madura Barat terjadi perlawanan yang dipimpin oleh Cakraningrat IV. ${ }^{62}$ Pada akhir 1744 , ekspedisi di bawah von Hohendorff berhasil merebut daerah-daerah yang dikuasai Madura. Para raja di daerah itu mulai tunduk kepada VOC, termasuk putra Cakraningrat IV dari Sedayu. ${ }^{63}$ Cakraningrat IV sendiri menyingkir ke Banjarmasin, ${ }^{64}$ meskipun akhirnya dapat ditangkap di sana. Cakraningrat IV kemudian diasingkan ke Kaap de Goede Hoop. Ia meninggal di tempat pengasingannya pada 1759. Atas dasar itu, orang Madura memberinya nama Pangeran Sidengkap.

Pada 1891, keraton Bangkalan telah dianggap bouwvalling (tidak layak dihuni) oleh pemerintah Hindia Belanda. Keraton Bangka-

nama anaknya ini, ayahnya pun sesudah meninggal juga disebut dengan nama Cakraningrat. Lihat, De Graaf dan Pigeaud, Kerajaan-Kerajaan Islam di Jawa Peralihan dari Majapahit ke Mataram.

60 Menurut Sadjarah Dalem, adik Sultan Agung dimaksud adalah putri Pajang. Dari perkawinannya ini melahirkan seorang putra bernama Panembahan Tengah. Lihat, De Graaf dan Pigeaud, KerajaanKerajaan Islam di Jawa Peralihan dari Majapahit ke Mataram, 214.

${ }^{61}$ Keturunan Tjakraningrat dengan Ratu Ibu atau Syarifah Ambani dapat dilihat pada silsilah yang terdapat di Asta Aer Mata Ibu, Madura.

${ }^{62}$ Sartono Kartodirdjo, Pengantar Sejarah Indonesia Baru: 1500-1900 Dari Emporium Sampai Imperium, Jilid I (Jakarta: Pustaka Utama, 1992), 237.

${ }^{63}$ Kartodirdjo, Pengantar Sejarah Indonesia Baru: 1500-1900 Dari Emporium Sampai Imperium, jilid I, 237-238.

${ }^{64}$ Kartodirdjo, Pengantar Sejarah Indonesia Baru: 1500-1900 Dari Emporium Sampai Imperium, 238. lan kemudian dirobohkan dan diganti dengan bangunan biasa. ${ }^{65}$ Hal tersebut sangat memilukan bagi masyarakat setempat yang menyadari nilai penting suatu peninggalan sejarah. Sedangkan pihak pemerintah berusaha menghilangkan ingatan (memory colective) mengenai kebesaran kerajaannya pada tempo dulu. ${ }^{66}$ Hingga di sini, sekalipun kerajaan Madura Barat telah dihapuskan oleh pemerintah Belanda, namun sejak berdiri pada 1531-1882, telah dipimpin oleh beberapa raja, sebagai berikut: (1) Pangeran Pratanu (Panembahan Lemah Duwur, 1531 - 1592), (2) Raden Koro (Pangeran Tengah, 1592 - 1620), (3) Pangeran Mas (1621 - 1624), (4) Raden Prasena (Pangeran Cakraningrat I, 1621 - 1624), (5) Raden Oendakan (Pangeran Cakraningrat II, 1648 1707), (6) Raden Toemenggoeng Soeroadiningrat (Pangeran Cakraningrat III, 1707 1718), (7) Pangeran Sidengkap (Pangeran Cakraningrat IV, 1718 - 1745), (8) Pangeran Sidomoekti (Pangeran Cakraningrat V, 1745 1770), (9) Raden Toemenggoeng Mangkoediningrat (Panembahan Adipati Pangeran Cakraadiningrat VI, 1770 - 1780), (10) Soelthan Abdoe/Soelthan Bangkalan I (P.A.P. Cakraadiningrat VII, 1780 - 1815), (11) Soelthan Abdoel Kadiroen (Soelthan Bangkalan II, 1815 - 1847), (12) Raden Yoesoef (Panembahan Cakraadiningrat VII, 1847 - 1862), dan Raden Isma'il (Panembahan Cakraadiningrat VIII, 1862 - 1882). ${ }^{67}$

\section{b. Para Raja Madura Timur}

Sebagaimana telah disebutkan pada pembahasan terdahulu, terdapat riwayat penting yang berasal dari masa pra-Islam tentang Sumenep. Saat itu Sumenep merupakan daerah kekuasaan Wiraraja atau Banyak Wide, seorang Adipati Singhasari. Wiraradja bernama lengkap Arya Adhikara Wiraraja. Ia memerintah di Sumenep pada 1269-1292.

\footnotetext{
${ }^{65}$ Syamsu As., Ulama Pembawa Islam di Indonesia dan Sekitarnya, 92.

${ }^{66}$ Nina Herlina Lubis (54 tahun, Ketua MSI Cabang Jawa Barat, Guru Besar Universitas Padjadjaran), wawancara oleh Wawan Hernawan, Madura, 20 November 2010.

${ }^{67}$ Memory, "Madura Menurut Catatan Sejarah."
} 
Sebelumnya ia menjabat Demung atau Nayapati Singhasari pada masa pemerintahan Visnü Wardhāna (1248-1268). Setelah Visnü Wardhāna mangkat, ia dipromosikan oleh Kèrtanāgara menjadi Adipati Sumenep. ${ }^{68} \mathrm{Di}$ sini ia mulai merintis berdirinya kerajaan Sumenep. Meskipun statusnya sebagai kerajaan bawahan, Sumenep kemudian berkembang cukup signifikan. Wiraraja dikenal sebagai ahli strategi militer. Dijumpai informasi, karena kemahirannya itu, raja Majapahit pertama dapat naik tahta berkat bantuan Sumenep. ${ }^{69}$

\section{Arya Wiraraja}

Arya Wiraraja dilantik sebagai Adipati pertama Sumenep pada 31 Oktober $1269 .^{70}$ Selama dipimpin Wiraraja, banyak kemajuan yang dialami Sumenep. Dari silsilah keturunan, Wiraraja adalah seorang pria yang berasal dari Nangka, Jawa Timur. Setelah dewasa tumbuh menjadi seorang yang memiliki pribadi dan kecakapan yang baik. Wiraraja secara umum dikenal sebagai seorang ahli dalam ilmu strategi militer dan penasihat militer. Analisisnya tajam dan terarah, sehingga banyak musuh yang kalah ketika berperang melawan pasukannya. Namun, dibalik kegemilangannya terdapat orang yang mau menyingkirkannya. Wiraraja sering disebut dukun (penasehat spiritual) bagi raja. $^{71}$

Pada usianya yang diperkirakan menginjak 35 Tahun, karier Wiraraja cepat menanjak. Ia meniti karir mulai dari sebagai Demung

\footnotetext{
${ }^{68}$ Abdurachman, Pengantar Sejarah Jawa Timur, 43. Lihat pula, Wiryoprawiro, Arsitektur Tradisional Madura Sumenep dengan Pendekatan Historis dan Deskriptif, 23-24.

${ }^{69}$ De Graaf dan Pigeaud, Kerajaan-Kerajaan Islam di Jawa Peralihan dari Majapahit ke Mataram,216. Lihat pula, Wiryoprawiro, Arsitektur Tradisional Madura Sumenep dengan Pendekatan Historis dan Deskriptif, 23.

${ }^{70}$ Berdasarkan informasi itu, pada perkembangannya sekarang tanggal 31 Oktober kemudian disepakati dan ditetapkan sebagai hari jadi Kabupaten Sumenep. Lihat, Akhmad, Lintasan Sejarah Sumenep dan Asta Tinggi Beserta Tokoh di Dalamnya, 5.

${ }^{71}$ Memory, "Madura Menurut Catatan Sejarah."
}

Kerajaan Singhasari, kemudian dipromosikan oleh Kèrtanāgara (Raja Singhasari) menjadi Adipati Sumenep. Setelah itu, Wiraraja dipromosikan oleh Raden Wijaya (Wijaya Nalaraja) menjadi Rakean Menteri di Kerajaan Majapahit dan bertugas di Lumajang. ${ }^{72}$ Seiring tugas barunya, Wiraraja meninggalkan Sumenep dan posisi adipati diserahkan kepada saudaranya, bernama Arya Bangah. Setelah Wiraraja pindah ke Lumajang, kerajaan di ujung Timur Madura mengalami kemunduran. Meskipun masih berada di Sumenep, keraton yang asalnya bertempat di Batuputih kemudian dipindahkan oleh Bangah ke Banasare. Selanjutnya penguasa Sumenep diganti oleh anak Arya Bangah, yaitu Arya Danoerwendo. Pada masa pemerintahannya, keraton Sumenep dipindahkan lagi ke Desa Tanjung. Arya Danurwendo selanjutnya diganti oleh anaknya, bernama Arya Asparati. Asparati kemudian diganti pula oleh anaknya, bernama Panembahan Joharsari.

Setelah Panembahan Joharsari, pemerintahan Sumenep dilanjutkan oleh putranya bernama Panembahan Mandaraja. Panembahan Mandaraja mempunyai 2 (dua) orang putra bernama Pangeran Bukabu dan Pangeran Baragung. Pangeran Bukabu kemudian menggantikan ayahnya sebagai penguasa Sumenep. Pada masa pemerintahan Bukabu, keraton yang semula berada di desa Tanjung kemudian dipindah lagi ke Bukabu (sekarang termasuk wilayah Kecamatan Ambunten). Pada masa selanjutnya, Pangeran Baragung naik tahta menggantikan kakaknya. Pada masa pemerintahannya, keraton dipindah lagi dari Bukabu ke desa Baragung (sekarang termasuk wilayah Kecamatan Gulukguluk).

\section{Raden Ayu Tirtonegoro dan Bendoro Sa'ud}

Raden Ayu Tirtonegoro ${ }^{73}$ merupakan satusatunya pemimpin wanita dalam sejarah kerajaan Sumenep sebagai kepala pemerintahan yang ke-30. Menurut hikayat, pada suatu malam Ratu --Raden Ayu Tirtonegoro--

\footnotetext{
${ }^{72}$ Marwati Djoened Poesponegoro dan Nugroho Notosusanto, Sejarah Nasional Indonesia, Jilid II, 424.

${ }^{73}$ Akhmad, Lintasan Sejarah Sumenep dan Asta Tinggi beserta Tokoh di Dalamnya, 33.
} 
bermimipi agar ia menikah dengan Bendoro Sa'ud. Setelah Bendoro Sa'ud dipanggil, diceritakanlah mimpi itu. Bendoro Sa'ud pun setuju. Tidak lama setelah itu pernikahan Ratu dan Bendoro Sa'ud dilaksanakan. Bendoro Sa'ud yang menjadi suami Raden Ayu Tirtonegoro kemudian bergelar Tumenggung Tirtonegoro. $^{74}$

Pada perkembangannya, masih pada pemerintahan Ratu Tirtonegoro terjadi peristiwa memilukan sekaligus tragis dalam Kerajaan Sumenep. Raden Purwonegoro, Patih Kerajaan jatuh hati kepada sang Ratu. Akibatnya, ia sangat membenci Bendoro Sa'ud, bahkan merencanakan untuk membunuhnya. Sampai pada suatu kesempatan, Raden Purwonegoro datang ke keraton sambil menghunus pedang. Ketika tiba di hadapan Bendoro Sa'ud, ia mengayunkan pedangnya. Hanya saja sabetan itu tidak mengenai sasaran, yang terjadi malah pedang Raden Purwonegoro tertancap dalam di tiang pendopo. Pada peristiwa itu, kejadian justeru sebaliknya, Raden Purwonegoro tewas di tangan Manteri Sawunggaling dan Kyai Sanggatarona yang saat itu berada di lokasi kejadian. ${ }^{75}$

Terdapat informasi, berdasarkan silsilah para raja Sumenep, bahwa Ratu Tirtonegoro dan Purwonegoro adalah sama-sama keturunan dari Tumenggung Yudonegoro, Raja Sumenep ke-23. Karena itu, jika hubungan mereka dilanjutkan, maka akan berdampak luas dan menyalahi tradisi turun-temurun Kerajaan Sumenep. Selanjutnya, sebagai akibat dari peristiwa tersebut, keluarga Kerajaan Sumenep terbagi menjadi dua kelompok. Pertama, kelompok yang berpihak kepada Ratu Tirtonegoro. Mereka diperbolehkan tetap tinggal di Sumenep dengan beberapa peraturan, di antaranya: (1) diwajibkan mengubah gelar kebangsawanan mereka dengan sebutan kyai; dan (2) berjanji untuk tidak akan menentang Bendoro Sa'ud sampai tujuh turunan. ${ }^{76}$

\footnotetext{
${ }^{74}$ Akhmad, Lintasan Sejarah Sumenep dan Asta Tinggi beserta Tokoh di Dalamnya, 34.

${ }^{75}$ Anonimous, "Selayang Pandang Sejarah Sumenep," Madura Studies, t.t.

${ }^{76}$ Anonimous, "Selayang Pandang Sejarah Sumenep."
}

Kedua, kelompok yang tidak setuju kepada ketentuan tersebut, mereka dianjurkan untuk segera meninggalkan Kerajaan Sumenep dan kembali ke Pamekasan, Sampang, atau Bangkalan. ${ }^{77}$

\section{Panembahan Semolo (Pangeran 'Asirudin bergelar Notokusumo I)}

Bendoro Sa'ud dengan isteri pertamanya (sebelum menikah dengan Ratu Tirtonegoro) di Batu Ampar mempunyai 2 (dua) orang putra. Pada saat kedua anak Bendoro Sa'ud datang ke keraton untuk memenuhi panggilan Ratu Tirtonegoro, anak kedua yang bernama Semolo terlebih dahulu "nyungkem" kepada Ratu. Sedangkan kakaknya mendahulukan menyungkem kepada ayahnya (Bendoro Sa'ud). Saat itu pula keluar wasiat sang ratu yang dicatat oleh sektretaris kerajaan. Isi wasiat menyatakan, bahwa kelak di kemudian hari apabila Bendoro Sa'ud meninggal, yang diperkenankan untuk mengganti menjadi raja Sumenep adalah Semolo. Selanjutnya, setelah Bendoro Sa'ud wafat 8 hari, Ratu Tirtonegoro menyusul ikut wafat. Peristiwa itu terjadi pada 1762. ${ }^{78}$ Dengan demikian, sesuai wasiat Ratu yang berhak menjadi Raja Sumenep adalah Semolo dengan gelar Panembahan Notokusumo I.

Beberapa peristiwa penting pada masa pemerintahan Semolo, di antaranya: Pertama, ia melakukan penyerangan terhadap Negeri Blambangan dan berhasil memenangkan pertempuran, sehingga Blambangan dan selanjutnya Panarukan (Pasuruan) menjadi wilayah kekuasaan Panembahan Notokusumo I. Ke$d u a$, ia membangun Keraton Sumenep yang sekarang berfungsi sebagai Pendopo Kabupaten. Ketiga, ia membangun Masjid Jami'

77 Anonimous, "Selayang Pandang Sejarah Sumenep."

${ }^{78}$ Panembahan Semolo dilantik dan dinobatkan oleh Gubernur Jenderal Petrus Albertus Vander Parra. Upacara pelantikan dilaksanakan di Semarang bersamaan dengan adipati Bangkalan Pangeran Setiadiningrat (Pangeran Cakraningrat V). Akhmad, Lintasan Sejarah Sumenep dan Asta Tinggi beserta Tokoh di Dalamnya, 38. 
pada tahun 1778-1787. ${ }^{79}$ Keempat, ia membangun Kompleks Asta Tinggi (tempat pemakaman para raja Sumenep dan keluarganya). ${ }^{80}$ Hingga sekarang bangunan tinggalan Panembahan Notokoesoemo I yang berupa Keraton Sumenep, Masjid Jami', dan Kompleks Asta Tinggi masih dapat dijumpai dan kondisinya terawat dengan baik.

\section{Abdurrahman Pakunataningrat}

Abdurrachman Pakunataningrat, bernama asli Notonegoro putra Panembahan Notokusumo I. Ia mendapat gelar doktor kehormatan dalam bidang Kesusastraan dari Pemerintah Kerajaan Inggris, karena pernah membantu Gubernur Jenderal Thomas Stanford Raffles ${ }^{81}$ untuk menerjemahkan tulisan-tulisan kuno pada batu ke dalam Bahasa Melayu. Abdurrachman Pakunataningrat memang meguasai berbagai bahasa, seperti: bahasa Sankskerta, Kawi, dan sebagainya. Atas kemampuannya itu, ia menguasai beberapa ilmu pengetahuan dan Agama. Selain itu, Abdurrachman Pakunataningrat mahir membuat senjata keris. Sepanjang hidupnya, ia dikenal sangat bijaksana dan memperhatikan rakyat Sumenep. ${ }^{82}$ Karena itu, ia sangat disegani dan dijunjung tinggi oleh rakyat Sumenep sampai sekarang.

Abdurrachman Pakunataningrat memerintah Sumenep antara 1811-1854. Berdasarkan masa pemerintahannya, sangat menjadi mungkin ia bertemu dan membantu Gubernur Jenderal Thomas Stanford Raffles sebagaimana disebutkan sebelumnya. Abdurrachman Pakunataningrat meninggal pada 31 Maret 1854 dalam usia 73 tahun. Jenazahnya kemudian dimakamkan di Asta Tinggi, satu atap dengan ayahnya, Panembahan Semolo.

\footnotetext{
${ }^{79}$ Akhmad, Lintasan Sejarah Sumenep dan Asta Tinggi beserta Tokoh di Dalamnya, 39.

${ }^{80}$ Akhmad, Lintasan Sejarah Sumenep dan Asta Tinggi beserta Tokoh di Dalamnya.

${ }^{81}$ Akhmad, Lintasan Sejarah Sumenep dan Asta Tinggi beserta Tokoh di Dalamnya, 41.

${ }^{82}$ Anonimous, "Selayang Pandang Sejarah Sumenep."
}

\section{SIMPULAN}

Madura telah menunjukkan eksistensinya dalam rangkaian sejarah para raja di Nusantara. Meskipun seperti terdapat pemisahan secara diametral dengan harus menyebut Madura Barat dan Timur, pada peristiwa perjalanannya memang ditemukan fakta demikian. Dari sisi asal-usul, meskipun belum ditemukan sumber bereputasi, keberadaan sumber tradisi yang mengaitkan peristiwa puteri Bendoro Gung dan Radin Segoro, menunjukkan bahwa perjalanan manusia menuju Madura berawal dari barat menuju ke daerah paling timur. Pada kesempatan lainnya, sejumlah prasasti dan naskah (kakawin, serat, kidung, dan babad) lebih banyak menempatkan peran orang-orang Madura timur.

Keberadaan Madura barat baru terungkap kembali pada masa Islam, dengan menempatkan perjalanan pangeran Pratanu ke Mataram yang kemudian kembali ke Madura Barat (Bangkalan). Perjalanan pemerintahan kerajaan di Madura Barat dimulai dari Pangeran Pratanu (Panembahan Lemah Duwur) di Aros Baya naik tahta pada 1531-1592, hingga Raden Isma'il (Panembahan Tjakraadiningrat VIII tahun 1862-1882, telah silih berganti sebanyak 13 raja. Sementara di kerajaan Madura Timur (Sumenep) telah dipimpin paling tidak oleh 35 orang raja, sejak Arya Wiraraja hingga Bendoro Abdurrachman. Madura memiliki bentangan sejarah yang panjang. Mereka kadang bersatu, dan sangat menjadi mungkin terjadi permusuhan dalam perjalanan sejarahnya yang panjang itu. Situasi dan kondisi itu terus berlanjut hingga Madura berada dalam pengaruh Vereenigde OostIndische Compagnie(VOC), dan pemerintah Kolonial Hindia Belanda.

\section{DAFTAR PUSTAKA}

Abdurachman. Sejarah Madura Selayang Pandang. Sumenep: The Sun, 1971.

Akhmad, Bendara. Lintasan Sejarah Sumenep dan Asta Tinggi Beserta Tokoh di Dalamnya. t.k.: Barokah, 2010.

-. "Selayang Pandang Sejarah 
Sumenep." Madura Studies, t.t.

De Graaf, H.J, dan TH. G Pigeaud. KerajaanKerajaan Islam di Jawa Peralihan dari Majapahit ke Mataram. Jakarta: Grafiti, 1985.

Djafar, Hasan. "Kerajaan Majapahit." Dalam Indonesia dalam Arus Sejarah, Jilid 2. Jakarta: Ichtiar Baru van Hoeve atas kerjasama dengan Kementerian Pendidikan dan Kebudayaan Republik Indonesia, 2012.

Garaghan, Gilbert J. A Guide to Historical Method,. New York: Fordham University Press, 1946.

Gottschalk, Louis. Mengerti Sejarah. Diterjemahkan oleh Nugroho Notosusanto. Jakarta: Yayasan Penerbit Universitas Indonesia, 1975.

Hardjowardojo, R. Pitono. Pararaton. Djakarta: Bhratara, 1975.

Kartodirdjo, Sartono. Pendekatan Ilmu Sosial dalam Metodologi Sejarah. Jakarta: Gramedia, 1992.

Larope, J., dan R. Soetedjo. Sejarah Indonesia. Surabaya: Asia-Afrika, 1975.

Lubis, Nina H. Metode Sejarah. Bandung: Satya Historika, 2008.

Marwati Djoened Poesponegoro dan Nugroho Notosusanto, Sejarah Nasional Indonesia, Jilid II, (Jakarta: Balai Pustaka, 1993)

Muhammad Syamsu As, Ulama Pembawa Islam di Indonesia dan Sekitarnya, (Jakarta: Lentera, 1996).

Muljana, Slamet. Menuju Puncak Kemegahan (Sejarah Kerajaan Majapahit). Yogyakarta: LKiS, 1985.

Mulyana, Slamet. Nāgarakrtāgama dan Tafsir Sejarahnya. Jakarta: Bhratara Karya Aksara, 1979.

Renier, G.J. Metode dan Manfaat Ilmu Sejarah. Diterjemahkan oleh A. Muin Umar. Yogyakarta: Pustaka Pelajar, 1997.

Santoso, Soewito. Babad Tanah Jawi (GaluhMataram). Delanggu: t.p., 1970.

Sartono Kartodirdjo. Pengantar Sejarah Indonesia Baru: 1500-1900 Dari Emporium Sampai Imperium. Jilid I.
Jakarta: Pustaka Utama, 1992.

Sjamsuddin, Helius. Metodologi Sejarah. Diterjemahkan oleh S. Aji. Yogyakarta: Ombak, 2007.

Wiryoprawiro, Zein M. Arsitektur Tradisional Madura Sumenep dengan Pendekatan Historis dan Deskriptif. Surabaya: Laboratorium Arsitektur Tradisional FTSP ITS Surabaya, 1986.

Wiyata, A. Latif. Mencari Madura. Jakarta: Bidik Phronesis Publishing, 2013.

Zoetmulder, P.J. Kalangwan Sastra Jawa Kuno Selayang Pandang. Diterjemahkan oleh Dick Hartoko Sj. Jakarta: Djambatan, 1974.

\section{Internet}

Anonimous. "Sejarah Asli Kerajaan Madura." Diakses pada 18 November 2010. http://dunia-pusaka.com/index.php?route=product/product\&product id=794.

Anton, Syaf. "Adat dan Kepribadian Orang Madura." Lomatar Madura. Diakses pada $15 \quad$ September 2016. http://www.lontarmadura.com/adat-dankepribadian-orang-madura-2/.

Lubis, Hamdani. "Sejarah Madura." Kabar Madura. Diakses pada 10 Januari 2016. http://kabarmadura07.blogspot.co.id/201 3/01/sejarah-madura.html.

Farisi, Moh. Imam. "Raja-Raja Sumenep Masa Pra Islam (1271 - 1527 M),." Lontar Madura. Diakses pada 1 Oktober 2016. http://www.lontarmadura.com/rajaraja-sumenep-masa-pra-islam-12711527-m/\#ixzz4LlaEnn6s.

Memory, Bangkalan. "Madura Menurut Catatan Sejarah.” Diakses pada 17 November 2010. http://www.bangkalanmemory.net/content/view/163/147/.

Scharlita, Famela Fitria. "Adat dan Kepribadian Orang Madura," 2013. http://famelasfitriascharlita.blogspot.co.i d/2013/02/adat-dan-kepribadian-orangmadura.html.

\section{Wawancara}

Aminudin Kasdi $( \pm 56$ tahun, Ketua MSI 
Cabang Jawa Timur dan Guru Besar Universitas Negeri Surabaya/UNESA). Wawancara oleh Wawan Hernawan. Madura, 19 November 2010.

Nina Herlina Lubis (54 tahun, Ketua MSI
Cabang Jawa Barat, Guru Besar Universitas Padjadjaran). Wawancara oleh Wawan Hernawan. Madura, 20 November 2010. 